\title{
Congenital Ventricular Tachycardia
}

National Cancer Institute

\section{Source}

National Cancer Institute. Congenital Ventricular Tachycardia. NCI Thesaurus. Code C101196.

An electrocardiographic finding of a tachycardia that originates in the ventricles that is present at birth. 